\title{
Medical technologies and the social strategies of two surgical instrument makers in Denmark and Sweden, 1870-1900
}

\begin{abstract}
Technical professions were important agents in medicine and its knowledge production in the nineteenth century. This paper will look more closely at two examples of the social strategies used by Danish surgical instrument maker Camillus Nyrop and his Swedish colleague, Max Stille respectively. Although the work of these two instrument makers attracted attention both within their respective countries as well as internationally, and they were regular fixtures in medical circles, their contributions have merited little academic interest thus far. By examining the social strategies used by nineteenth century technicians, in this case surgical instrument makers, we might better understand the interrelationships between technical professions and physicians in the knowledge production of modern medicine and the interplay between medicine and commerce.

Keywords: history of medicine, history of medical instruments, surgical instrument makers, medicine in Sweden, medicine in Denmark, history of technology.

A semi-regular addition in the Danish medical journal Ugeskrift for Lager during the latter decades of the nineteenth century were articles authored by the surgical instrument maker and bandagist Camillus Nyrop. ${ }^{1}$

1 "Bandagist" is the Danish word for what would approximately be equivalent to an orthotist today. During the period of study, bandagists often worked with the construction and application of mechanical braces and trusses for the treatment of illnesses
\end{abstract}


Similarily, in Sweden, Max Stille and his father Albert Stille were frequent contributors to the Swedish Society of Medicine's meetings, presenting medical instruments and devices and offering commentary. Many of their contributions presupposed familiarity with medical scientific discussions and close contact with physicians. Their engagement illustrates the ways that technical professions made use of their professional contacts and social status in order to navigate specialist spaces in nineteenth century medicine. Their interests were professional; however, given the nature of their work, it is difficult to separate them from the commercial natures of their businesses.

In this paper, I will begin with a brief overview of the main actors, the two surgical instrument makers mentioned above, Camillus Nyrop and Max Stille. These two men were privileged in their professions and should not be understood as representative for the trade as a whole in Sweden and Denmark, but offer insight into work of more privileged technicians. I will then examine two cases as examples of the social strategies used by surgical instrument makers in Sweden and Denmark in the latter half of the nineteenth century. By social strategy, I mean the ways these instrument makers took advantage their respective local contacts and their specific needs in order to promote their commercial and professional interests. $^{2}$ The first case is a review of a hernia truss by Danish instrument maker Camillus Nyrop in the Danish medical journal Ugeskrift for Loeger from 1878. This case looks at Nyrop's social position in relation to a competitor and the claims made in the competitor's patent of a hernia truss.

such as scoliosis and hernias. I have chosen to use the Danish terminology. During the period of study, bandagists were hardly professionalized and their relationships with physicians were sometimes contentious due to the work of itinerant practitioners dealing in the sale and application of mechanical orthopedic devices who called themselves bandagists. My forthcoming dissertation will examine this in greater detail, see K. Halverson, "Tools of the Trades: Medical Devices and Historical Meanings in Sweden and Denmark, 1850-1900" (preliminary/forthcoming Diss., Stockholm: Södertörn University, 2022). David LeVay discusses professions which fulfilled similar functions in the British and French contexts in his book The History of Orthopaedics. However, his brief chapter on orthopaedics in Scandinavia does not mention their role, nor many of the actors involved in this article. This merits further investigation. See David LeVay, The History of Orthopaedics: An Account of the Study and Practice of Orthopaedics from the Earliest Times to the Modern Era, (Lancashire: The Parthenon Publishing Group, 1990): 79, 237, 323-335.

2 See Stuart Blume, Insight and Industry: On the Dynamics of Technological Change in Medicine, (Cambridge, MA: MIT Press, 1991), 57. 
The second case is a presentation of a heatable operating table by Swedish instrument maker Max Stille in the Swedish medical journal Hygiea from 1897. The second case examines the social element behind technological innovation, namely the construction of a new operating table by Stille according to practitioners' specifications. Together, these two cases provide insight into the social strategies used by these nineteenth century surgical instrument makers in promoting and discussing their work and its engagement with medicine.

This study will draw on previous research by Takahiro Ueyama, John Pickstone, Jonathan Reinarz and Claire Jones in particular, all of which look at the relationships between technical professions, commerce and medicine and/or relations between commerce and medicine. Much like Ueyama illustrates in his book Health in the Marketplace, there has been longstanding collaboration between medical practitioners and technicians in device production, and, as both Ueyama and Jones underline, the medical profession has never been divorced from commercial interests, something which underpins the two cases that I examine below. ${ }^{3}$ Importantly, however, these studies examine British contexts. Rather than merely confirm the results of these studies, albeit in different geopolitical and scientific contexts, I will employ some geographic sensitivity, and look rather at how social strategies operated in Swedish and Danish contexts by using these two cases in particular. ${ }^{4}$

3 See Takahiro Ueyama, Health in the Marketplace: Professionalism, Therapeutic Desires, and Medical Commodification in Late-Victorian London, (Palo Alto, California: The Society for the Promotion of Science and Scholarship, 2010), 8, 210 211; Claire L. Jones, "A Barrier to Medical Treatment? British Medical Practitioners, Medical Appliances and the Patent Controversy, 1870-1920," British Journal for the History of Science 49, no. 4 (December 2016): 603.

4 There has been some interest in similar themes using Swedish and Danish materials in the history of science. Just a few examples are: Olov Amelin, "Medaljens baksida: Instrumentmakaren Daniel Ekström och hans efterföljare I 1700-talets Sverige" (Diss., Uppsala University, 1999); Hjalmar Fors, "Mutual Favours: the Social and Scientific Practice of Eighteenth-Century Swedish Chemistry" (Diss., Uppsala University, 2003); Hjalmar Fors, "Medicine and the Making of a City: Spaces of Pharmacy and Scholarly Medicine in Seventeenth-Century Stockholm," Isis 107, no. 3 (September 2016); and, Helge Kragh, "Out of the Shadow of Medicine: Themes in the Development of Chemistry in Denmark and Norway," in The Making of the Chemist: The Social History of Chemistry in Europe, 1789-1914, eds. David Knight and Helge Kragh (Cambridge: Cambridge University Press, 2008). 


\section{Representative or unique? Who were \\ Camillus Nyrop and Max Stille?}

Both Camillus Nyrop and Max Stille were well-respected and renown instrument makers, not only in their respective national medical circles but also internationally, attracting attention in France, England and Germany, for example. ${ }^{5}$ In turn, they both occupied unique and privileged positions in their crafts and should not be understood as representative for their profession in either country. ${ }^{6}$

5 An osteotome of Camillus Nyrop's construction was praised by both French and English physicians, meriting mention in The Lancet, even. Nyrop was also wellknown outside of Denmark for his orthopedic devices and participated in a number of World's Fairs and other, European expositions. Around the turn of the century, Max Stille worked closely with German surgeon and gynecologist Karl August Schuchardt, who was based in Stettin (modern Szczecin) on the development of an operating table (not the one discussed in this article). Stille additionally sold operating tables across Europe, to the United States and Egypt, and furnished an operating theatre in St. Petersburg. See for example Camillus Nyrop, Bandager og Instrumenter afbildede og beskrevne med en tilføi et Prisfortegnelse (Copenhagen: G.E.C. Gad, 1864), [introduction not paginated]; C. Nyrop. Camillus Nyrop og det kirurgiske Instrumentmageri $i$ Danmark, (Copenhagen: Nielsen \& Lydiche, 1884), 110-111 [note: source is not autobiographical and was written by Nyrop's son and namesake, Camillus (1843-1918), who was a historian of Danish industry.]; "The Great International Exhibition. II. Report on Surgical Instruments," The Lancet 79, no. 2020 (May 17, 1862): 524-525; [Anon.], "Erkännande från Amerika åt svensk industri", Smålandsposten, Feburary 9, 1894, [not paginated]; [Anon.], "Stilles operationssal vid läkarekongressen i Rom," Stockholms Dagblad, April 22, 1894; [Anon.], "Bilder från svenskt industri- och näringslif. Alb. Stilles kirurgiska instrumentfabrik," Aftonbladet, February 21, 1903.

6 There were at least twenty-five surgical instrument makers and/or bandagists working in Denmark in the nineteenth century and at least nine workshops of varying sizes and output in Sweden during the same period. See Nyrop, Camillus Nyrop, 119-121; Peter Gullers, Verktygsmakare \& operatörer: Några aspekter på den kirurgiska instrumenttillverknings svenska historia, Report/Arbetslivscentrum: 37, (Stockholm: Arbetslivscentrum, 1982). Gullers' report misses at least two workshops in the city of Uppsala, those of Johan Rabén and Anders Nyman, though he notes problems with accurate statistics regarding profession from the nineteenth century. Rabén and Nyman eventually began making velocipeds, see Jean-Paul Darphin, Nymans verkstäder: cykelgiganten i lärdomsstaden Uppsala (Uppsala: Industrihus, 1995).

Importantly, in order to establish any kind of overview of the trade's scope, I have had to look at sources other than medical journals. Journals profile only the Stilles and Nyrop to any significant degree, and Stockholm-based Ch. O. Werner and Copenhagen-based Anton Rasmussen appear only occasionally. See Stockholm stadsarkiv, Hall- och manufakturrätten SE/SSA/0099, B3: 53-56; Uppsala Universitet, Medicinska fakulteten, GI: Räkenskaper. 
In the 1840s, Camillus Nyrop and Max Stille's father, Albert Stille, received stipends from their respective governments to undertake training abroad. ${ }^{7}$ In Nyrop's case, he had previously apprenticed as a turner and a metalworker, but after his training, he quickly became interested in surgical instrument making and went abroad to study this trade. ${ }^{8}$ Both Nyrop and Albert Stille spent time in Paris studying under the renown French master cutler and surgical instrument maker Joseph-Frédéric-Beniôt Charriére, and both established themselves as surgical instrument makers at schools of medicine in 1841: Camillus as the Danish Surgical Academy's instrument maker and Albert as the Karolinska Institute's surgical instrument maker. Max Stille continued in his father's footsteps, first by studying abroad to learn the trade. Max also took over leadership of the business in 1884 after his father's death, but had been involved as a foreman and co-owner prior to that. Max was also eulogized in Hygiea by surgeon John Berg, after his untimely death in 1906, where Berg detailed the close relationship Stille had with Swedish and German physicians in particular. ${ }^{9}$ In addition to their association with the Karolinska Institute, the Stille's were both members of the Swedish Society of Medicine and frequently participated in society meetings, where they displayed their devices and instruments, in particular new constructions or modifications of other instruments. ${ }^{10}$ Though Nyrop was not a member of the Danish Medical Society, he frequently published in the Danish medical journals Ugeskrift for Lager and Hospitalstidende

7 C. Nyrop, Slagten Nyrop: Nogle biografiske oplysninger (Copenhagen: Nielsen \& Lydiche, 1908), 87; John Berg, "Minnesteckning: Max Stille”, Hygiea 68, no. 1 (April 1906): 358-363.

8 Nyrop, Slagten Nyrop, 86. Nyrop also spent time in Berlin and Vienna studying his trade. See also Nyrop, Camillus Nyrop, 61. These books are not autobiographical, rather written by surgical instrument maker Camillus Nyrop's son, who shared the same name but worked as a historian.

9 See John Berg, “Minnesteckning: Max Stille”, Hygiea 68, no. 1 (April 1906).

10 Surgical instrument maker Ch. O. Werner was also elected a member of the Swedish Society of Medicine in 1894. See Förhandlingar vid Svenska läkarsällskapets sammankomster, February 27, 1894. Werner and Stille's firms merged together to form Stille-Werner AB in 1910, four years after Max Stille's death in 1906.

For some of the Stilles' contributions, see Förhandlingar vid Svenska läkarsällskapet, February 25, 1873; March 18, 1873; May 20, 1873; November 25, 1873; October 9, 1877; November 6, 1877; July 13, 1878; November 2, 1878; November 9, 1878; November 11, 1878; November 23, 1878; February 22, 1881; March 29, 1881; February 19, 1895; October 8, 1895; November 12, 1895. 
and was one of the few pens not belonging to a physician published in these periodicals. ${ }^{11}$

The successes of both Nyrop and the Stille in their respective home countries and abroad were tied into the close contact they had established with physicians and medical societies, and the social function of these relationships. Takahiro Ueyama, John Pickstone, Jonathan Reinarz and Claire Jones are just a few researchers who have examined the close relationships between technical and commercial professions and medicine in the nineteenth and twentieth centuries. ${ }^{12}$ Ueyama, for example, stresses the historiographical problems in identifying medicine's complex relationship with commercial actors and commodity culture in his book Health and the Marketplace. He additionally underlines the importance of collaboration between physicians and technical professions in order to construct devices that actually work as needed. ${ }^{13}$

Claire Jones makes a similar point in an article on medical patents in the late nineteenth and early twentieth centuries, stating that the medical profession has never operated outside the influences of commerce. ${ }^{14}$ Jones furthermore illustrates in her case study that professional norms did not always translate seamlessly to individual practice and opinion. While Jones looks particularly at medical practitioners in her study, she points

11 The Danish bandagist Anton Rasmussen also published a number of articles in Ugeskrift for Lager during the same period; however, not to the same degree Nyrop did. Rasmussen's articles often presented his work and though they were not specifically advertisements, they read as such. Nyrop was more active in discussions involving medical devices, orthopedics and even those involving his profession and work. See for example Anton Rasmussen, "Endu et Par Ord om Patteflasker med Metalsugerør", Ugeskrift for Lager, Series 3, Vol. 1, No. 7 (February 3, 1866), $102-$ 103; Anton Rasmussen, "Bekjendtgjørelse", Ugeskrift for Lager, Series 3, Vol. 3, No. 12 (March 2, 1867): 183. The former article was a defence against a previous article which criticized children's bottles with straws Rasmussen's firm had sold that had allegedly contaminated milk; whereas, the latter introduces a hydrotherapy institute opened by Rasmussen in Copenhagen.

12 Some other studies include Joseph M. Gabriel, Medical Monopoly: Intellectial Property Rights and the Origins of the Modern Pharmaceutical Industry (Chicago: The University of Chicago Press, 2014); Claire L. Jones, The Medical Trade Catalogue in Britain, 1870-1914 (London: Pickering \& Chatto, 2013); Julie Anderson, Francis Neary and John V. Pickstone, Surgeons Manufacturers and Patients: A Transatlantic History of Total Hip Replacement (Basingstoke: Palgrave Macmillan, 2007).

13 Ueyama, Health in the Marketplace, 179 \& 210.

14 Jones, "A Barrier to Medical Treatment?," 603. 
out that looking at individual cases might reveal closer alignments to commerce than have been previously known in the medical profession. While I would contest that Nyrop and Stille's interests in medicine were solely commercial, their seemingly unproblematic presence in Danish and Swedish medical circles offer insight into this alignment, albeit in different contexts and under different terms in that Jones studies physicians. Further, John Pickstone highlights the social and moral meaning of histories of technology in his study of bone-setters in Lancashire where he also examines the linkages between the medical profession and the ancillary work of bone-setters and the role of industry in medical development. In Jonathan Reinarz' study of medical innovations in voluntary hospitals in Birmingham, he encourages historians to move away from the notion of linearity in the adoption of innovation. Rather, complex factors such as social networks played important roles in the diffusion of medical technologies in nineteenth century charity hospitals in the Birmingham area. ${ }^{15} \mathrm{In}$ my cases, the social networks of these two instrument makers places them in privileged positions, which allowed them to assess the work of others, as one case will show, and promote their own work, as the other case highlights, in medical periodicals.

However, these studies are geographically similar: they study British contexts and British materials, and my research should not be understood as a broad extrapolation over context-specific regions. Pickstone, for example, highlights the benefit of analytical interaction between the general and the specific in histories of technology. ${ }^{16}$ The two cases I study here work from the broader understanding of the deployment of social interaction in innovation studies, but within two locally specific frames. Furthermore, by studying the interactions between Nyrop, Stille and physicians in their respective countries within the frame of socially contingent joint construction and production of knowledge, technicians are understood as important agents in knowledge production. And an important locally specific factor in

15 Jonathan Reinarz, "Mechanizing Medicine: Medical Innovations and the Birmingham Voluntary Hospitals in the Nineteenth Century," in Devices and Designs: Medical Technologies in Historical Perspective, eds. Carsten Timmermann and Julie Anderson (Basingstoke: Palgrave Macmillan, 2006), 39.

16 John V. Pickstone, "Bones in Lancashire: Towards Long-term Contextual Analysis of Medical Technology," in Devices and Designs: Medical Technologies in Historical Perspective, eds. Carsten Timmermann and Julie Anderson (Basingstoke: Palgrave Macmillan, 2006), 18. 
the reputations of these two workshops was the push to build up and modernize expertise in these kinds of skilled trades to limit the need to look abroad for similar expertise.

Due to their contacts, they occupied privileged positions in their trade in both countries. To be sure, they were not the only instrument makers in Sweden and Denmark during the period between 1850 and 1900 approximately; however, they are the only ones who figure as frequently in medical journals, which attests to their social status and relationships with physicians and the importance of these contacts. In addition to this, the businesses established - in Nyrop's case - or inherited - in Stille's case - still exist, albeit in different forms. ${ }^{17}$ With this in mind, the following two examples will explore the relationships between their social status and how they navigated and present their expertise in medical journals.

\section{Camillus Nyrop and the hernia truss}

In December 1878, Camillus Nyrop challenged the practicality of a new hernia truss in an article published in the Danish medical journal Ugeskrift for Laeger and, albeit somewhat indirectly, lifted the question of whether or not patents could be read as marks of quality and/or usability. Nyrop's article was a response to an article written by Danish physician Sigfred Levy a few weeks prior, who had written about the truss in relation to the question of patenting in Ugeskrift. Levy had been keen to test a promising hernia truss made by Prussian Emil Edel; however, Edel "[had] patented them in every country". ${ }^{18}$ Patents had yet to be legislated in Denmark, but Levy implored the editor and readership of Ugeskrift to

17 The parent company of Stille-Werner AB went bankrupt in 1993; however, the rights to Stille were rescued from the estate and Stille AB operates to this day in Torshälla, Sweden, approximately 120 kilometres west of the capitol Stockholm. Nyrop's sons Louis and Johan Ernst took over their father's workshop after his death in 1883. The company was later merged with Hjalmar Maag A/S. Nyrop \& Maag is currently a subsidiary of Sahva A/S, located in Brøndby, in the capitol region of Denmark.

18 Sigfred Levy, "Om Kjæderbrokbaand Efter Emil Edel. Arch. f. klin. Chir. XXII. 3)," Ugeskrift for Laeger, Series 3, Vol. 26, No. 28 (December 14, 1878): 435. Noteworthy, "every country" which Levy refers to included neither Sweden nor Denmark.

Note: All translated quotes in this article are my own translations. Readers interested in the original quotations are encouraged to contact me; whereby, I will happily provide them. 
formulate a general stance on patenting, suggesting opposition toward patents of inventions of a humane character. ${ }^{19}$ Importantly, Denmark did not have patent legislation at the time, and, in a response to Levy's article, the editor of Ugeskrift, Vilhelm Budde, noted the lack of exclusions for medical devices in patent legislation elsewhere, which might lead to significant resistance if employed in a similar way in Denmark. ${ }^{20}$ In other words, a professional stance against the patenting of medical innovations was superfluous in the Danish context. ${ }^{21}$

The following week after Budde's editorial response, Camillus Nyrop offered commentary which assessed the truss in the context of its patent, where the question of patents as marks of quality came up indirectly in his critique. He commended the proliferation of new devices "to the public to serve suffering human beings [and] offer them relief", but also stated that "it is equally important and necessary to attempt to examine the purported merits of the new agent in relation to the old, before it is praised". ${ }^{22}$ There were better and more readily available hernia trusses in circulation, according to Nyrop, and he could not "with the best will... uncover any advantage [and] for the practitioner there are simple trivialities which raise suspicion". ${ }^{23}$ In his article, Nyrop analyzed both the mechanics and principles behind Edel's device and concluded that the truss could not live up to its expectations: it could not deliver the necessary amount of pressure and there were other, better alternatives. Though Levy's article lamented the patent as a hinderance to the proliferation of beneficial medical devices, Nyrop concluded that patents themselves were not particularly useful mark for practitioners to judge practical merits, but that they "may look good in an advertisement". ${ }^{24}$

19 Levy, "Om Kjæderbrokbaand”, 435.

20 See V. Budde, "Et Par Bemærkinger om Patenter," Ugeskrift for Lager. Series 3, Vol. 26, No. 29 (December 21, 1878): 454.

21 Claire Jones discusses medical patenting in the British context significantly in her article. See in particular pp. 606-613. Claire L. Jones, "A Barrier to Medical Treatment? British Medical Practitioners, Medical Appliances and the Patent Controversy, 1870-1920," British Journal for the History of Science 49, no. 4 (December 2016): 601-625.

22 Camillus Nyrop. "Kjæderbrokbaand”, Ugeskrift for Lager. Series 3, Vol. 26, No. 30 (December 28, 1878): 469.

23 Nyrop, "Kjædebrokbaand", 471-472.

24 Ibid., 470, 471-472. 
The truss' American patent highlighted the advantages this truss had over others, pointing out improvements on previous designs and that other trusses could be injurious. ${ }^{25}$ Nevertheless, whether Edel's claims were true or not was not up to the patent authorities to decide, rather, they examined the newness of Edel's technological innovation. ${ }^{26}$ Nyrop's critique called both the claims made in Edel's patent as well as the function of the truss into question, and he stated at the end of the article that many of the claims Edel made in the patent were either inconsequential to treatment or issues that would make a well-seasoned practitioner suspicious. ${ }^{27}$ But Nyrop would have also been aware of the tacit dimensions of truss construction and use, something that would not necessarily have been implicit in patents, which communicate technical details. That is to say, the patent would have highlighted the truss design and construction, but not the unarticulated, hands-on work involved in both. ${ }^{28}$ Nyrop's familiarity with truss construction, by constructing trusses himself, puts Edel's patent in different light. In addition to this, he worked closely with several physicians in treating patients with the help of orthopedic devices, which would have given him clinical insight into common orthopedic problems and their treatments, such as hernias and scoliosis. ${ }^{29}$ As mentioned previously, Nyrop was initially trained as a turner and metalworker and later undertook further training as a surgical instrument maker. He

25 Emil Edel. Improvement in Trusses. 1877. United States Patent US198586A, filed July 14, 1876, issued December 25, 1877.

26 See for Denmark Lov nr. 69 af 13 April 1894, Patentlov. Stadfcestet af Hs. Maj. Kong Christian IX den 13de April. See for Sweden SFS 1884:25, Kongl. Maj:ts nådiga förordning angående patent.

27 Nyrop, “Kjæderbrokbaand", 472.

28 Michael Polanyi famously wrote that, "We can know more that we can say". Michael Polanyi, The Tacit Dimension (New York: Doubleday \& Company, 1966), 4. See also Katherine T. Durack, "Tacit knowledge in patent applications: observations on the value of models to early US Patent Office practice and potential implications for the 21 st century," World Patent Information 26, no. 2 (June 2004): 131-136; Margaret McInerney, "Tacit Knowledge Transfer with Patent Law: Exploring Clean Technology Transfers," Fordham Intellectual Property, Media and Entertainment Law Journal 21, no. 2 (2011): 449-493.

29 See for example Camillus Nyrop, [Advertisement], Göteborgs Handels- och sjöfartstidning, April 4, 1866; Camillus Nyrop, “Om Virksomheden som kirurgisk Instrumentmager og Bandagist," Ugeskrift for Lager. Series 4, Vol. 5, No. 21 (May 6, 1882): 313-326. 
was well-versed in metalwork, and his work was praised in newspaper articles and at exhibitions. ${ }^{30}$

Still, Nyrop's relationships with Danish physicians potentially interested in Edel's truss, such as Sigfred Levy who drew Nyrop's attention to it, would have offered a distinct professional advantage for him, that other instrument makers less socially involved in Danish medicine would not have had, not the least Edel himself, as he was German. Stuart Blume notes in his book Insight and Industry the importance of local connections in the proliferation of technologies, where the social implications of these connections are important aspects of the activity of technical firms in medicine. Furthermore, while social networks could offer important areas of contact for different actors, they also harnessed the possibility of local actors "[erecting] barriers to entry to a given market, while differentiating one's product from potentially competing products". ${ }^{31}$ Perhaps unwittingly, Edel had also erected a barrier himself by patenting the truss in the first place, which according to Levy, hindered its proliferation.

Additionally, although Nyrop did not directly promote his work in the article on Edel's truss, his contributions to Danish orthopaedics would have been well-known due both to his status within Danish medicine and his contributions to Ugeskrift for Lager which sometimes included information about his own devices. In addition to this, he authored a book, Bandager og Instrumenter which was first published in 1864 with two further editions, published in 1868 and 1877 respectively. Bandager og Instrumenter illustrated devices Nyrop's firm sold, often but not always of his own invention. The book was sold widely, and was reviewed several times in Ugeskrift for Lager, which means the average Danish physician would have at least been aware of it, if not having a copy in their bookcase.

30 See for example an article on the Paris International Exposition in 1856, which commented on his work [Anon.], Fadrelandet, January 15, 1856, 46. Several other newspaper articles reporting about the London Internationa Exposition in 1862 make mention of Nyrop's skill. See [Anon], Fadrelandet, June 2, 1862; [Anon.], Fyens Stiftstidende, August 22, 1862; and [Anon.], "Beretning om Udfaldet af Verdensutdstillingen i London 1862 for Koneriget Danmarks Hertungdømmet Slesvig Bekommende," Lolland-Fasters Stifts-Tidenene. May 31, 1863.

Additionally, Nyrop identified the importance of metalwork in the construction of orthopedic braces and trusses in an article from the 1880s in Ugeskrift for Lager. See Camillus Nyrop, “Om Virksomheden som kirurgisk Instrumentmager og Bandagist", Ugeskrift for Lager. Series 4, Vol. 5, No. 21 (May 6, 1882): 313-326.

31 Blume, Insight and Industry, 58. 
Nyrop would not have had to promote his work: Danish physicians would have been familiar with it already. The truss example paints a picture of the social function of introducing new innovations, where Edel may have been at a disadvantage, not having the close contact with Danish physicians that its introduction may have required, nor the direct opportunity to defend it from Nyrop's critique.

\section{Max Stille's operating table}

In February 1897, an article by the Swedish surgical instrument maker Max Stille was published in the Swedish Society of Medicine's journal Hygiea. Typically reserved for scientific papers, clinical results and translated summaries of foreign publications, Stille introduced one of the many operating tables of his construction and his article is one of the only examples of a non-physician publishing in this journal during the period 18701900. ${ }^{32}$ Stille's article profiled a heatable table, designed for laparotomies and gynecological operations of his own construction. ${ }^{33}$ In the article, Stille emphasized both the table's practicalities as well as its connections to demand. For example, the table could be moved easily, was compact compared to other alternatives, could be bolted to the floor for stability as well as positioned in various ways. Additionally, the head support was adjustable in such a way that it mitigated the risk of showering the patient's head with bodily and lavage fluids and the stirrups for the legs were "even of a new design and positioned so that they cannot lead to compression of the blood vessels in the knees or folds of the groin". ${ }^{34}$

32 I have done a systematic reading of Hygiea from 1850-1900 for my PhD thesis, and while it is possible that I have missed a contribution without having looked up every author, the Stille's were such frequent contributors to society meetings that they lack comparison in the Swedish context. I have furthermore cross-referenced this with Hygiea's indexes over proper names 1849-1860; 1861-1870; 1871-1880; 1881-1888; and, 1889-1898.

33 His tables were discussed several times in newspapers as well. See for example, [Anon.], "Erkännande från Amerika åt svensk industri," Smålandsposten Smålandsposten, Feburary 9, 1894; [Anon.], "En mönster-operationssal," Dagens nyheter, February 28, 1894; [Anon.], "Bilder från svenskt industri- och näringslif. Alb. Stilles kirurgiska instrumentfabrik," Aftonbladet, February 21, 1903.

34 Max Stille. Operationsbord för laparotomier och gynekologiska operationer [Operating Table for Laparotomies and Gynaekological Operations]. Hygiea 59, no. 2 (February 1897): 290. 
Much like Nyrop, Stille used his technical knowledge as well as his relationship with practitioners in order to highlight the advantages of his table. For example, he noted the practical demand for the modifications he made. He stated for example that the table's heatable element was due to the "encouragement from several operators". ${ }^{35}$ In Hygiea, presentations of individual devices or medical instruments were not common additions, and the few from the period were profiled by physicians, some who had modified the apparatus in question, but not by instrument makers who had a direct stake in the sale and proliferation of what they were presenting. A few examples of articles of these kinds were also table-related and touched on problems Stille's table purported to resolve such as mobility, albeit in different ways.

The 1890s provides a few examples of physicians tackling tablerelated problems. One physician, Carolina Widerström, worked together with a carpenter to construct a table with moveable slabs in 1890. Another, S. Lindström, had a sofa-like examination table constructed in 1894 so that the height of the bed could be adjusted, and it could be set in different positions. ${ }^{36}$ Lindström's table looked more like parlour furniture than an examination table. These examples illustrate that there was some demand for tables with moveable parts, and that physicians were solving these problems themselves, with technical help. Both Widerström and Lindström provided descriptions of their tables/beds, who made them, and in Lindström's case, where one could place an order. ${ }^{37}$ And Stille's table also worked to problemsolve, with its movable parts. ${ }^{38}$ By framing his modifications against experienced practical issues and clear demand given physician-lead solutions by Widerström and Lindström, he shows his familiarity with physicians' work and the discourse of device practicality in medical circles at the time. Furthermore, by emphasizing practical issues, Stille's work was, at least to some degree, empirically grounded and an example of joint knowledge production between physicians and technicians - physicians experienced these problems and found solutions to mitigate them, in the case of Widerström's

35 Stille, "Operationsbord," 289.

36 Förhandlingar vid Svenska läkarsällskapets sammankomster, 11 March 1890; S. Lindström. "En ny medicinsk möbel," Hygiea 56, no. 4 (April 1894): 364.

37 Lindström, "En ny medicinsk möbel", 365.

38 Stille, “Operationsbord”, 290; and, Stille, Lyftinrättning vid operationsbord, sjuksängar m.m., Swedish patent SE4720C1, filed July 5, 1893, issued November 18, 1893. 
and Lindström's modifications mentioned above and Stille produced a solution. John Pickstone makes a similar point in his study of bone-setters in Lancashire, where medical practice in the early nineteenth and twentieth centuries was largely empirical, and not necessarily grounded in new physiological or pathological discoveries. ${ }^{39}$ But, in highlighting his table as offering practical solutions to present problems, Stille could ease the tensions of its newness as well.

Sally Frampton, for example, points out in her research on ovarian surgery, that innovation was often understood as introducing instability. ${ }^{40}$ Stille mitigated some of the instability and "newness" involved with the device by highlighting both the practical advantages of this table, noted above, as well as its modifications and how they corresponded to the demands of not one, but several practitioners. His deployment of the table's practicalities as well as demand for certain features could have worked tactically to calm the nerves of skeptical practitioners. Stuart Blume notes that emphasizing the safety and stability of a device is an aspect of its successful diffusion. ${ }^{41}$ By connecting it to demand (or request) and noting its utility, Stille was ensuring that this new table was stable, both according to standards as well as perceived need, which served to mitigate the unease of instability. ${ }^{42}$ Each solution was presented in relation to a problem: placement of the tubing; mobility of different parts; problems achieving the right temperature with other, heatable tables; the inability of the physician to see the patient whilst adjusting the table with different bolt systems; problems with rusting bolts and difficulty cleaning if placed too close to the floor. ${ }^{43}$ Still, the existence of practical issues actualised a market for solutions, of which Stille could provide.

39 Pickstone, "Bones in Lancashire," 23.

40 Sally Frampton, "Defining Difference: Competing Forms of Ovarian Surgery in the Nineteenth Century" in Technological Change in Modern Surgery: Historical Perspectives on Innovation, eds. Thomas Schlich and Christopher Crenner (Rochester: University of Rochester Press, 2017), 66.

41 Blume, Insight \& Industry, 6.

42 In a different context, see for example Sally Frampton, "Defining Difference: Competing Forms of Ovarian Surgery in the Nineteenth Century," in Technological Change in Modern Surgery: Historical Perspectives on Innovation, eds. Thomas Schlich and Christopher Crenner (Rochester: University of Rochester Press, 2017), $51-70$.

43 Stille, "Operationsbord," 289-290. 


\section{Conclusions}

In this article, I have examined two cases that highlight the social implications of medical device construction and proliferation in nineteenth century Sweden and Denmark. Both surgical instrument makers in question had similar career trajectories with close associations through medical schools, medical societies and professional journals. They should not be understood as representative of surgical instrument makers in these two countries as a whole, but rather two, prominent examples of how social networks figured into their prominence and recognition which provided them with resources and allowances to promote or block the introduction of new technologies in their respective circles. Furthermore, because of their social capital, they had a better understanding of what demand might have existed and how they could provide solutions, than a surgical instrument maker that was less active in physician-dominant circles and less acclimatized to discussions in professional journals.

In the first case, I discussed a hernia truss which was criticized in the Danish medical journal Ugeskrift for Laeger by surgical instrument maker Camillus Nyrop. Nyrop's case highlights the relationships between technical and tacit knowledge and what kind of information patents communicate about an innovation. But it is also an example of blocking the introduction of a technology as a social strategy and using one's reputation and expertise as a means of assessment. Nyrop and his work were well-known and Edel's likely much less so and while Nyrop was in the position to assess Edel's hernia truss, Edel would not have been able to offer a rebuttal. The second case examined an article written by Swedish surgical instrument maker Max Stille in the country's medical journal Hygiea. Stille's presentation of his newly designed heatable operating table was in relation to both practical demand and problem-solving. He noted in the article that the table was constructed due to multiple demands on behalf of physicians and other articles and commentary indicate that physicians were actively looking to mitigate and solve practical problems with other tables. Stille would have been aware of this due to his social network, being a member of the Swedish Society of Medicine and his late father's connections to the medical school Karolinska Institute in Stockholm. Furthermore, by emphasizing both the practicalities of and demand for his table, he would have mitigated some of the instability involved in new innovations. It alleviated some practical problems and some of the solutions it allegedly provided practitioners were requested. 
Zooming out for a moment, both these studies offer insight into the ways nineteenth century technicians navigated their social networks. Both articles can be read as advertisement - either promotion of a more person-specific character in relation to Nyrop's article, or that of an innovation more specifically, in Stille's case. In the aforementioned studies by Ueyama and Jones, they point out the longstanding relationship between medicine and commerce, where zooming in to individual practitioners muddles the image of a profession strictly against commercial interests, as was projected in Britain. Pickstone and Reinarz additionally highlight the importance of social factors both in relation to technological innovation in nineteenth century medicine as well as their proliferation. The cases in this article also help to provide insight in this regard by looking closer at two strategies and at the local factors in device proliferation, as well as further problematizing the notion of a medical practice divorced from commercial interest. Finally, this study illustrates that closer examination of social networks in relation to surgical instrument making merits further investigation by historians interested in the innovation and proliferation of nineteenth century medical technologies and the joint knowledge production between surgical instrument makers and other technical actors, and medical practitioners.

\section{Medicīniskās tehnoloǵijas un divu ķirurğisko instrumentu izgudrotāju sociālās stratēǵijas Dānijā un Zviedrijā laikposmā no 1870. līdz 1900. gadam}

\section{Kopsavilkums}

Tehniskajām profesijām ir bijusi svarīga loma medicīnas nozarē un tās zināšanu radīšanā 19. gadsimtā. Šajā publikācijā kā piemērs ir padziļināti aplūkotas sociālās stratēǵijas, kādas izmantoja dāṇu ķirurǵisko instrumentu ražotājs Kamiluss Nairops (Camillus Nyrop) un viņa zviedru kolēgis Makss Stille (Max Stille), lai reklamētu, popularizētu savu darbu un veicinātu tā izmantojumu medicīnā. Lai gan šie divi instrumentu izgudrotāji piesaistīja uzmanību gan savās valstīs, gan arī starptautiskā līmen⿳亠̄ un regulāri apgrozījās medicīniskajās aprindās, viṇu ieguldījums līdz šim ir izpeln̄ijies maz akadēmiskās intereses. Pētot 19. gadsimta tehniķu, šajā 
gadījumā - ķirurǵisko instrumentu izgudrotāju, izmantotās sociālās stratēǵijas, var labāk izprast savstarpējo saikni starp tehniskajām profesijām un ārstiem attiecībā uz mūsdienu medicīnas zināšanu radīšanu un medicīnas un tirdzniecības mijiedarbību.

Atslēgvārdi: medicīnas vēsture, medicīnisko instrumentu vēsture, ķirurǵisko instrumentu izgudrotāji, medicīna Zviedrijā, medicīna Dānijā, tehnoloğiju vēsture.

\section{Kristin Halverson}

Baltijas un Austrumeiropas Augstskola, Sodertornas Universitāte, Zviedrija /

Baltic and East European Graduate School,

Södertörn University, Sweden 